\title{
ECOTOURISM AS A SOFT SKILL PRACTICE FOR MILLENIALS
}

\author{
I Dewa Gde Satrya, Thomas Stefanus Kaihatu, Lexi Pranata \\ Universitas Ciputra Surabaya, Indonesia
}

\begin{abstract}
Traveling not only creates fun for tourists. Tourism activities are believed to also improving human resources ability. It is a significant aspect related to human resource capacity that soft skills ownership which can be trained to modern travellers through ecotourism activities. This descriptive qualitative study describes soft skills trained to tourists from among younger generation in ecotourism destinations. Statement of the problem in this research is what is the relevance between ecotourism and soft skill ownership? This study identifies soft skills trained in ecotourism activities that are interpersonal skills characterized by communication skills, like others, have empathy and concern, warm, forgiving, open, adaptive and self-control abilities. The interpersonal skills that are part of this soft skill are believed to be important and will help younger generation to succeed in living their lives.
\end{abstract}

Keywords: eco-tourism, soft skills

\section{ACKNOWLEDGMENT}

This article is one of the Outcomes of Research Grant, DRPM Ministry of Research, Technology and Higher Education, Republic of Indonesia (2019).

\section{INTRODUCTION}

Currently the young generation has a wide range of choices in channelling the wishes of a trip. Ecotourism is one option. It is realized that this tourism genre outside of the mainstream, much preferred by today's younger generation who tend to want to explore for a new experience.

This opportunity is in line with the 1980 Manila Declaration, one of which says tourism should not ignore social problems. This is one of the crucial roles of the tourism sector is to improve the quality of life as also stated in the World Tourism Code of Ethics.
First, tourism aims to build mutual understanding and mutual respect among the population and society. Secondly, tourism is a means to improve the quality of life. Third, tourism is part of sustainable development. Fourth, tourism is a user and contributor to cultural heritage preservation. Fifth, tourism is a profitable activity for the country and the recipient community of tourists. Sixth, the obligations of tourism stakeholders. Seventh, basic rights of travel. Eighth, freedom of movement for tourists. Ninth, the workers right in tourism industry. Tenth, implementation of the code of ethics. Former Tourism Minister I Gede Ardika also stated similarly, tourism can improve the life quality by studying other tangible and intangible cultures of the nation, including studying local life-changing policies (Venue Magazine, April 2010, pp. 87-88).

The ten idealisms were adopted in Law Number 10 of 2009 on Tourism. Related to the

\footnotetext{
*Corresponding Author.

e-mail: dewa.gde@ciputra.ac.id

https://doi.org/10.37715/jee.v8i2.1121
} 
I Dewa Gde Satrya, Thomas Stefanus Kaihatu, Lexi Pranata / Ecotourism as a Soft Skill Practice for Millenials / JEE, Vol. 7, No. 2, September 2019, pp 57-64

improvement of life quality, soft skill ownership is believed to be a significant part that will help every individual succeed in his life. Values and skills that are part of soft skills become a tool for individuals to be able to improve their quality life. The mechanism of values cultivation and soft skill ownership training through tourism activities, particularly to travel in ecotourism villages, will be identified through this research.

As is known, characteristics of ecotourism villages consist of a combination of several important elements, including conservation, environment, local culture. Three essential elements that characterize ecotourism to be explored by tourists are also important elements of contemporary life.

Another phenomenon that became thinking in this study is, about the workplace challenges that filled young generation today. Job search competition in the business world is increasingly competitive. This can be seen from the increasing number of unemployed graduates in Indonesia. Number of the national lebur force in the first year of the economic crisis (1998) was about 92.73 million, while number of employment opportunities was only about 87.67 million people and there were about 5.06 million were open unemployment. This number increased steadily during economic crisis until in 2006 about 8 million people. The number of college graduates also continues to increase. By 2000 there are about 2.3 million labour force of college graduates. Limited employment opportunities for college graduates have an impact on the growing number of unemployed undergraduates in Indonesia. According to the Directorate General of Higher Education report, number of unemployed undergraduates is more than 300,000 people (www.dikti.go.id).
Data above shows that job opportunities become increasingly rare, while number of college graduates more and more. Or it can be said that supply more than the existing demand. In addition, the empirical phenomenon that is often conveyed by the employment providers from business employer and industry, states, the gap qualifications of graduates who are less able to meet the community needs, that is the graduate's soft-skills. Therefore, the statement of the problem in this research is what is the relevance between ecotourism and soft skill ownership?

Nugroho and Negara (2015) define ecotourism as a professionally packaged, trained and educational travel activity, as an economic sector/enterprise, which considers cultural heritage, participation and welfare of the local population as well as efforts to conserve natural resources and the environment. The ecotourism concept can be used to develop tourist villages and build villages in general.

Nugroho (2017) defines operational characteristics of ecotourism services as follows:

- Efficient and slim (people, management, resources)

- It consists of small groups ( $<25$ people).

- Accommodation less than 100 beds (local SMEs).

- Systematic and comprehensive educational elements.

- Requires a skilled, smart and dedicated specialist guide

Ecotourism according to The Ecotourism Society in Fandeli (2000) is a form of tourism travel to a natural area undertaken with the aim to conserving environment and preserving the lives and welfare of the local population. Understanding about ecotourism has evolved over time. However, in essence, definition of ecotourism is 
a form of tourism that is responsible for preservation area that is still natural (natural area), provide economic benefits and maintain the cultural integrity for the local community. On the basis of this understanding, the ecotourism form basically is a form of conservation movement conducted by the world's population. This eco-traveller is essentially conservationist.

Some principles of ecotourism characteristics Maulana (2016) that distinguish them from mass tourism, are as follows:

- Reduce negative impact of damage or pollution of the environment and local culture due to tourism activities.

- Building awareness and appreciation to the environment and culture in tourist destinations, both in tourists, local communities and other tourism actors.

- Offers positive experiences for tourists and local people through more intensive cultural contacts and collaborating in maintenance or Objects conservation and Tourist Attraction.

- Providing direct financial benefits for conservation purposes through extra tourist contributions or expenditures.

- Providing financial benefits and empowerment to local communities by creating tourism products that promote local values.

- Increase sensitivity to social, environmental and political situation in tourist destinations.

- Respect for human rights and employment agreements, in the sense of giving freedom to tourists and local people to enjoy tourist attractions as a form of human rights, and subject to fair rules and mutually agreed upon in the conduct of tourist transactions with good and precise.

A study of the National Association of College and Employees (NACE) 2002 put the cumulative grade point in colleges at $17^{\text {th }}$ rank. The value obtained in the university which has become one of the critical requirements in the labour recruitment, is now no longer dominant. GPA is now under the skill of computer skills, organizational skills, and leadership. However, communication skills, cooperation, interpersonal, ethics, initiative, adaptation, and analytics are still more important than above computer skills. These skills, more commonly referred to as soft-skills, are more needed in the workforce $(80 \%)$ while hard-skills are only $20 \%$ of them (Sailah, 2008). Unfortunately, these soft-skills sciences are overlooked in most curriculum designs in college. In general, the higher education curriculum focuses on the ability to master science and field of study skills or hard-skills.

\section{METHOD}

This research is qualitative approach. In accordance with the theme that has been stated, then the goal to be achieved in this research is to describe soft skill is trained to tourists from among younger generation in ecotourism destinations.

Primary data sources were acquired through interviews and observations of young people who visited Wonosalam ecotourism village during 2017. Beside, primary data sources also came from business and industry interviews in hospitality, both as an owner and senior director level. Secondary data sources are gained through relevant references. Secondary data were obtained through related literature studies. Other primary data sources are taken by purposive sampling, where the most focal sampling is how to determine key informants or specific social situations that are full of information according to the research focus. 
I Dewa Gde Satrya, Thomas Stefanus Kaihatu, Lexi Pranata / Ecotourism as a Soft Skill Practice for Millenials / JEE, Vol. 7, No. 2, September 2019, pp 57-64

Data analysis is the process that regulates data sequence, organizes it into a basic pattern, category, and description. Data analysis as a process detailing the formal effort to find theme and formulate idea as suggested by data, and in an effort to provide assistance on the theme and idea (Aries, 2010). Analysis of data collected in this study using descriptive analysis approach which is a specific approach to qualitative data analysis. Researchers collected informants from tourism study program students. They took an ecotourism experiment tour from the researchers. Then they were interviewed about the experience of doing an ecotourism trip. Data analysis was carried out through triangulation of data sources, with ecotourism experts (Prigi Arisandi) as information centres. The answers from the information were triangulated from the opinion of the ecotourism expert.

\section{RESULTS AND DISCUSSION}

Based on interviews of business actors in the field of hospitality, the demand to young people who will fill the work world is the standard of ethical and moral ownership, courtesy. Some of the complaints of business actors are, firstly, the value of high grade achievement index but does not guarantee positive personality and behaviour. Often found that such graduate models have low responsibilities, lack of etiquette, untidy-looking, rigid or poor communication, low fighting power and lack of courage to face challenges, often avoiding jobs that are not considered their duties, too maintain prestige.

In the early stages of interview and selection process, the fresh graduate often fails because, firstly, less initiative to find out the company profile, less able to convey ideas, lack of communication skills, low analytical and critical thinking, less smile and less confidence. Are travel activities in ecotourism villages an effective learning space to instil soft skill values among younger generation?

A report released by the United Nations World Tourism Organization revealed several new trends and developments in the world of tourism that began to emerge in the 1990s. With tendency of the young generation to back to the nature, then public interest to travel to the natural places more and more. Such interest is a driving factor for the ecotourism or tourism developed to the natural environment conservation-oriented.

Ecotourism experts and practitioners do not have a unanimous agreement yet on the formulation or definition of ecotourism. However, there are principles of ecotourism that consists of $8 \mathrm{key}$ principles that can be used as a guide. First, it has a natural focus area that allows tourists have opportunity to enjoy nature personally and directly. Second, provide interpretations or educational services that provide opportunities for tourists to enjoy nature so they become more understanding, able to appreciate and enjoy more. Third, the best activities that can be done in the context of ecological sustainability. Fourth, contribute to nature conservation and cultural heritage. Fifth, contribute continuously to the local community. Sixth, appreciate and sensitive to the cultural values that exist in the region. Seventh, consistently meet consumer expectations. Eighth, marketed and promoted honestly and accurately so that reality is in line with expectations (Arida, 2009).

Wonosalam ecotourism village in Dusun Mendiro, Panglungan Village, which was created by Ciputra University and Ecoton NGOs 
with funding support from the Ministry of Research, Technology and Higher Education through the Partner Village Development Program scheme, is run with a community-based tourism approach. Where, the public has opportunity to manage services for tourists such as lodging, tour guides, souvenirs providing that come from local culture and flora-fauna.

This is in line with the opinion of ecotourism expert, Manuaba in Arida, (2009) which asserted, ecotourism in addition to mass tourism antithesis, is also one of the steps toward sustainable development. Meanwhile, tourism activities are considered sustainable if they meet the four requirements: (1) ecologically sustainable, i.e. tourism development does not cause negative effects for the local ecosystem. In addition, conservation is a necessary effort to protect the natural and environmental resources from negative effects of tourism activities; (2) is socially acceptable, i.e. refers to the ability of local communities to absorb tourism activities without causing social conflict; (3) culturally acceptable, meaning that local people are able to adapt to a quite different tourist culture; (4) is economically profitable, meaning that the profits derived from tourism activities can improve welfare.

Ecotourism tourists visit from youth, designed through rural lectures, provides an overview of the benefits gained through communitybased rural tourism and environmental conservation. Field lecture program designed so that students form environmental insight, it actually gives deep impression of noble values formed through social interaction during tour activity. From this perspective, the impression gained by tourists in experiments in Wonosalam ecotourism village during 2017 which is reported in this article will be a foothold for ecotourism village development program design which will be- come a learning space for embedded soft skill values among young generation.

In this research, the concept of ecotourism destination engagement is referred to as Hollebeek's customer brand engagement, which is a level of cognitive, emotional, and or behavioural interaction with a brand. The activity itself is more proactive from the side of the customer (Hollebeek, 2011). Previous empirical research shows the nomology of consumer engagement with its antecedents and consequences. In the tourism studies, consumer engagement is shaped by involvement (Harrigan et al., 2017).

The design of this program considers following matters that have relevance to the youth ecotourism market:

- The working world demand on hard-skills and soft-skills are increasingly up. While educational activities during this time many lead to hard-skills improvement.

- Soft-skills set-up in students means changing the negative old character to the expected one. Developing soft-skills takes time, process, and continuous programs from the beginning to the end of the lecture.

As discussed in the introduction, a large gap exists between what required by industry on the performance of graduates within the soft skill ownership framework in particular. In an effort to collect soft-skills data of any kind that is trained by tourists from among younger generation, the following facts are obtained and described in Table 1.

Opinion from five informants who are tourists who visit Wonosalam ecotourism village for more than once for the interest of field coursework further emphasize that soft skill is related to the skills needed for the success of every individual in living life, especially personal life and will impact to family life, as well 
I Dewa Gde Satrya, Thomas Stefanus Kaihatu, Lexi Pranata / Ecotourism as a Soft Skill Practice for Millenials / JEE, Vol. 7, No. 2, September 2019, pp 57-64

Table 1 Soft Skill's Values from Traveling Experience

\begin{tabular}{|c|c|c|}
\hline Traveller Name & Tourist Activities & Interpretation of Attitudes and Soft Skills Formed \\
\hline 1. AS & $\begin{array}{l}\text { "Exploring forests and } \\
\text { springs in the dusun } \\
\text { Mendiro needs excellent } \\
\text { physical readiness in } \\
\text { order to enjoy tracking } \\
\text { that tracks up and down" }\end{array}$ & $\begin{array}{l}\text { Willingness to strive, physically striving, and in } \\
\text { other words work hard to achieve goals, becomes } \\
\text { a real challenge among today's young people who } \\
\text { have been accustomed to being facilitated in } \\
\text { getting daily needs. Ease and instant things gained } \\
\text { daily, making young people difficult to have the } \\
\text { will to work hard, and have a formidable attitude } \\
\text { to always want to solve the problems faced }\end{array}$ \\
\hline 2. SA & $\begin{array}{l}\text { "Interacting with } \\
\text { community leaders who } \\
\text { become tour guides, and } \\
\text { tracking villages that } \\
\text { support ecotourism } \\
\text { attractions to create } \\
\text { social program plans" }\end{array}$ & $\begin{array}{l}\text { Sometimes academic ability and achievement will } \\
\text { not be a guarantee of easy interaction with } \\
\text { different social environments. Interaction process } \\
\text { with community leaders who become tour guides } \\
\text { with the aim of making a social program in the } \\
\text { village, requires struggle and motivation to } \\
\text { develop themselves. The dialogue process to } \\
\text { design a social program that is not once so, } \\
\text { requires patience and resilience to proceed. } \\
\text { Knowledge of human character and how to face } \\
\text { it, lobbying skills, long life learning, how to dig } \\
\text { information from other parties, networking with } \\
\text { various circles, and creativity to create solutions, } \\
\text { become a significant part that must be owned by } \\
\text { the young generation. }\end{array}$ \\
\hline 3. $\mathrm{ME}$ & $\begin{array}{l}\text { "Exploring the Forests, } \\
\text { Springs and Rivers is } \\
\text { tiring, unattractive to say } \\
\text { as a tourist activity for } \\
\text { fun" }\end{array}$ & $\begin{array}{l}\text { Fact that young people today tend to be } \\
\text { comfortable, get a position without going to } \\
\text { bother first. In the world of work there are often } \\
\text { complaints from employment providers about } \\
\text { weak fighting spirit, commitment, maturity in } \\
\text { facing the problems, and integrity among college } \\
\text { products today. The uneasy, and usually } \\
\text { unpleasant, terrain, in rural ecotourism activities, } \\
\text { is a contradiction to the enjoyment gained by } \\
\text { urban civilization. It is precisely because of this } \\
\text { that community-based ecotourism characteristics } \\
\text { and environmental conservation will be able to } \\
\text { help create a resilient young generation of field- } \\
\text { faced exercises and the inconvenience of } \\
\text { ecotourism village situations. }\end{array}$ \\
\hline 4. HP & $\begin{array}{l}\text { "Gain new knowledge } \\
\text { about the diverse tree } \\
\text { species, which apparently } \\
\text { have many benefits for } \\
\text { human health and life" }\end{array}$ & $\begin{array}{l}\text { Living experience in a different social environ- } \\
\text { ment completely new to this generation, is } \\
\text { needed to awaken their knowledge of new and } \\
\text { foreign things that they need to master in the } \\
\text { future. This value is to anticipate complaints of } \\
\text { business actors and employment providers, that } \\
\text { most graduates are blind to the world of work. } \\
\text { The need for communication skills can be trained } \\
\text { through experience following ecotourism } \\
\text { activities. }\end{array}$ \\
\hline
\end{tabular}




\begin{tabular}{|l|l|l|}
\hline 1. DW & $\begin{array}{l}\text { "Can not relax, body } \\
\text { tired, but must continue } \\
\text { to follow the route } \\
\text { specified" }\end{array}$ & $\begin{array}{l}\text { Phenomenon of the younger generation who live } \\
\text { life with a relaxed and no goal of life, becomes a } \\
\text { pity reality. Mentality of seeking shortcuts to } \\
\text { achieve goals, also worries us all. Tracking } \\
\text { process of exploring forests, springs, and rivers } \\
\text { necessitates time-management, adaptability and } \\
\text { caring for others. Often they are provoked by } \\
\text { emotions against unpleasant things from others. } \\
\text { Caring for others trained through ecotourism } \\
\text { activities will reduce emotional decision making, } \\
\text { caring for others and ego-centric. }\end{array}$ \\
\hline
\end{tabular}

as social environment in the workplace as well as the community and the state. Soft skill ownership is increasingly necessary, especially interpersonal skills in communication and language, emotional stability

\section{CONCLUSION}

This study identifies soft skills trained in ecotourism activities is interpersonal skills consisting of communication skills, liked by others, empathy and caring, warm, tolerant, open, adaptive and self-control. Ability to communicate and be liked by others is trained through interaction between tourists with local guides and local people, adaptability, empathy, caring and tolerance with rural environments trained through tracking activities in forests, rivers and villages. The learning space to nurture specific ownership of interpersonal skills in ecotourism activities is expected to be an essential resource for individuals to successfully overcome the difficulties and challenges in life.

\section{REFERENCES}

Arida, S. (2009). Meretas jalan ekowisata Bali: proses pengembangan, partisipasi lokal, dan tantangan ekowisata di tiga desa kuno Bali. Udayana University Press.
Aries, E. F. (2010). Design action research. Malang: Aditya Media Publishing.

Fandeli, C. (2000). Pengertian dan konsep dasar ekowisata. Yogyakarta, Fakultas Kehutanan UGM. Retrieved from https://www.academia.edu/5188123/Ekowisata PENGERTIAN DAN KONSEP DASAR_EKOWISATA

Harrigan, P., Evers, U., Miles, M., Daly, T. (2017). Customer engagement with tourism social media brands. Tourism Management, 59, 597-609.

Hollebeek, L. D. (2011). Demystifying customer brand engagement: Exploring the loyalty nexus. Journal of Marketing Management, 27(7-8), 785-807.

Maulana, Y. (2016). Usulan Pengembangan Ekowisata Jayagiri Berbasis Masyarakat Lokal. Jurnal Hospitality dan Pariwisata, 2(2), 124-149. Retrieved from https://journal. ubm .ac.id/index.php/hospitality-pariwisata/ article/download/901/797.

Nugroho, I., \& Negara, P. D. (2015). Pengembangan Desa Melalui Ekowisata. Era Adicitra Intermedia, Solo.

Nugroho, I. D. (2017, September). Pembangunan desa melalui ekowisata, Paper presented at Public Discussion on the Development of Village Autonomy in the Postgraduate Program, Universitas Widyagama, Malang, 
I Dewa Gde Satrya, Thomas Stefanus Kaihatu, Lexi Pranata / Ecotourism as a Soft Skill Practice for Millenials / JEE, Vol. 7, No. 2, September 2019, pp 57-64

Indonesia. Retrieved from https://widyagama.ac.id/r2012/wp-content/uploads/2017 109/desa-wisata-presentasi-PPsUWG.pdf

Sailah, I. (2008). Pengembangan soft skills di perguruan tinggi, Paper presented at Soft Skills Development Socialization in Universitas Sebelas Maret, Surakarta, Indo- nesia. Retrieved from https://www.academia.edu/21713482/PENGEMBANGANSOFT SKILLS DI PERGURUAN TINGGI_Oleh_ILLAH_SAILAH_Kepala_Pusat_Pengembangan_SDM-LPPM_IPB Tim Pengembang_Soft_Skills_DIKTI. 